\title{
FOUR DECADES PERIOD OF CLIMATIC DATA FOR ASSESSING THE AEOLIAN HAZARD IN THE REGION OF TOUGGOURT (LOW ALGERIAN SAHARA)
}

\author{
Nouar BOULGHOBRA ${ }^{1}$, Nä̈ma KOULL ${ }^{1}$, Tidjani BENZAOUI
}

DOI: $10.21163 / G T \_2016.111 .03$

\begin{abstract}
:
Using the model of Fryberger and Dean (1979), wind data from Sidi-Mahdi airport weather station covering for decades (1975-2014), were analyzed to calculate sand drift potential and its derived parameters: resultant drift potential, resultant drift direction and the wind directional variability index. Results showed that highest potential sand transport corresponded to the spring season (113 Vector Unit). The annual drift potential was about $258 \mathrm{VU}$; this allowed classifying the region of Touggourt among the intermediate-energy wind environment. Low wind directional variability was detected $(0.33)$, and indicates the wind regime complexity and that winds blow from different directions; this complexity is due to interaction of winter westerlies and summer northerlies and north-easterlies effective winds. Resultant drift direction was estimated to be 320 degrees, and signifies that the moving sands are transported toward the southeast. Climatic data have been used to calculate sand dune mobility index of Lancaster (1988). Results showed that during the four decades period, dune mobility index was well superior to 200 indicating fully active dunes during the considered period. The study showed as well that the sand encroachment risk in Touggourt is certainly related to the physio-climatic environment, but the inappropriate human action could be an amplifying factor of the aeolian hazard.
\end{abstract}

Key-words: Drift potential, Wind regime, Wind environment, Dune mobility, Sand encroachment.

\section{INTRODUCTION}

In arid environments, surface wind is the main element responsible for transporting and depositing sand sediments (Mainguet, 1991). Speed, direction and frequency are the main wind elements that define the wind effectiveness. Nevertheless, only powerful winds which reach the threshold velocity can have the erosive activity (Bagnold, 1941).

In aeolian geomorphology, drift potential is the concept used for assessing the aptitude of sand transport. Among different models, the model developed by Fryberger and Dean (1979) is widely used for assessing the amount and direction of sand deposit transport, this model is based on wind data and has been performed depending on many different formulae, which have been derived based on various environmental assumptions to fit experimental data (Greeley \& Iversen, 1985). In addition to wind energy, sand dune mobility depends on vegetation cover, which refers to other critical climatic variables such as precipitation and potential evapotranspiration (Wasson, 1984; Lancaster, 1988). Thus, sand dunes are mostly mobile under arid climate and, their accumulation could be an environmental concern for the neighboring communities.

\footnotetext{
${ }^{1}$ Scientific and Technical Research Center on Arid Regions (CRSTRA), 30200 Touggourt, Algeria, boulghobra.n@gmail.com; kllnaima@gmail.com;tedjani72@yahoo.fr.
} 
Belonging to the north Sahara desert, Algeria is facing the major impacts of the aeolian hazard (Bensaid, 2006; Boulghobra, Hadri \& Bouhana, 2014; Boulghobra, Merdas \& Lakhdari, 2015). Further south, the region of Touggourt occupies the northeastern margin of the Grand Erg oriental dune system, this latter represents an important sand source, which could threat the surrounding settlements, infrastructures and palm groves. The importance of Touggourt city exists in its central location from which it lies at the junction of the N. 3 and N. 16 national roads, which connect to multiple neighboring cities and agglomerations. As a result of important wind events, the railroad section in vicinity of Touggourt is often invaded by sand, and all traffic activities are completely suspended.

This research aims to investigate the aeolian hazard in the region of Touggourt, by quantifying the sand drift potential and sand dune mobility based on climatic data. Accordingly, recommendations will be suggested in the context of risk mitigation.

\section{DATA AND METHODS}

\subsection{Study area}

Touggourt takes part of the Oued Righ valley which occupies the northwestern margin of the Grand Erg Oriental between latitudes $32^{\circ} 53^{\prime} ; 34^{\circ} 10^{\prime}$ north and the longitudes $5^{\circ} 47^{\prime}$; $6^{\circ} 10^{\prime}$ east (Fig. 1).
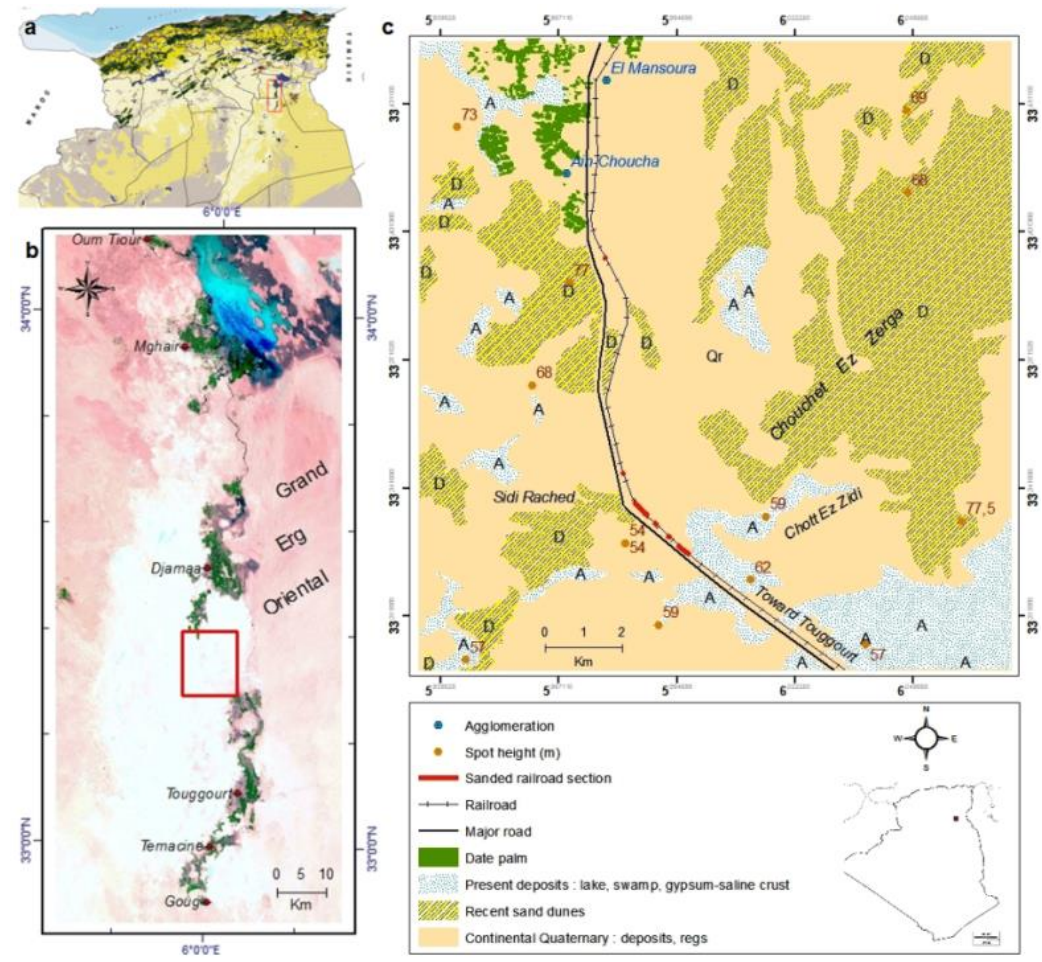

Fig. 1 (a) Location of Oued Righ valley in Algeria; (b) Location of the study area in Oued Righ valley based on TM Landsat image (2000); (c) Simplified geomorphology of the study area, based on the topographic map (1: 100 000), TM Landsat image (2000) and field investigation. 
The Oued Righ valley extends about $160 \mathrm{~km}$ from El Goug in the South to Oum Tiour in the North with an average width ranging between 15 and $30 \mathrm{~km}$ (Bisson, 2003). The cross section shows the top of the Mio-Pliocene outcrops consist of gypsum marl, and training of the early Pleistocene, characterized by Gypsy-limestone crust covered with dune formations (Erg). These formations are present in the study area and are covered with sandy sediments interspersed with salty clay lenses (Cornet, 1961).

As the whole Low Sahara, Touggourt belongs to the arid climate area, characterized by drought, significant thermal amplitude and long-term insulation (3000 hours/year). Precipitations are scarce and temporally irregular (Dubief, 1953; Ozenda, 1991). The average annual rainfall is about $69 \mathrm{~mm}(1975-2014)$ and the average annual temperature is $22.2{ }^{\circ} \mathrm{C}$ with a minimum of $10.6{ }^{\circ} \mathrm{C}$ in January and a maximum of $34.2^{\circ} \mathrm{C}$ in July. Annual relative humidity ranges around $44.8 \%$ and average annual wind speed is $3.1 \mathrm{~m} / \mathrm{s}$.

\subsection{Wind data and potential of sand drift}

Complete and reliable hourly surface wind measurements at $10-\mathrm{m}$ height covering the period 1975 - 2014, were obtained from the meteorological station Sidi-Mahdi airport (Lat. 33.7; Long. 6.09; Alt. 85m), the nearest station from the study site. In total, 167515 observations are summarized by velocity values $(\mathrm{m} / \mathrm{s})$ and directions (degree). These data have been used to calculate the amount of sand drift potential and its derived parameters.

The simplified formula of Fryberger and Dean (1979) is widely used and suggests expressing the relative amount of sand migration on vector unit (VU) as follows:

$$
Q=U^{2}(U-D t) t
$$

Where $Q$ is the relative amount of sand drift on vector unit, given that $1 \mathrm{VU}$ of drift potential corresponds to $0.07 \mathrm{~m}^{3}$ of sand creep across $1 \mathrm{~m}$ land width; $\bar{D}$ is the average wind velocity at $10-\mathrm{m}$ height; $D t$ is the threshold wind velocity; ${ }^{t}$ is the time wind blew expressed in percent and; and $D^{2}(U-D t)$ is a weighting factor, that depends on the wind strength in terms of velocity and occurrence.

The value of the weighting factor is divided by 100 to reduce the magnitude and simplify the plotting of sand roses. Further, the obtained drift potential should be divided on 12.5 when wind velocities are expressed in $\mathrm{m} / \mathrm{s}$ (Callot, 1987).

Threshold velocity is the minimum required wind speed to initiate sand grains moving; it is mainly a function of surface and air conditions, size and density of sand grains, surface roughness, rate of vegetative cover, and sand humidity (Bagnold, 1941; Chepil \& Woodruff, 1963; Belly, 1964). According to Fryberger and Dean (1979), 6 m/s (12 knots) could be considered as threshold velocity when sediment surfaces consist of dry and loose sand $(0.25-0.30 \mathrm{~mm}$ diameter), with sparse vegetation cover and no bedform roughness greater than ripples. From the equation (1), three parameters can be derived:

The resultant drift potential $R D P$ which refers to the net drift potential in term of magnitude, it is obtained by summing $D P$ for each direction. According to Al-Awadhi, AlHelal and Al-Enezi (2005), RDP could be calculated as follows: 


$$
R D P=\sqrt{C^{2}-D^{2}}
$$

where:

$C=\sum(V U) \sin (\partial)$

$D=\sum(V U) \cos (\partial)$

Where $W D$ represents the amount of the corresponding $D P$ for each wind direction in vector unit, and $\partial$ is the midpoint of orientation wind classes.

The resultant drift direction $R D D$ represents the sand transport direction. Referring to Al-Awadhi, Al-Helal and Al-Enezi (2005), the RDD is calculated as:

$$
R D D=\operatorname{atan}(C / D)
$$

The unidirectional index $\frac{R D P}{D P}$ is the ratio of the resultant drift potential to the drift potential, it ranges from 0 to 1 and expresses the wind directional variability; lower $\frac{R D P}{D P}$ values indicate significant directional variability, while higher values indicate that the wind blows from the same direction. According to Fryberger and Dean (1979), wind environment can be classified on low-energy wind environment (DP $<200 \mathrm{VU})$, intermediate-energy wind environment $(200<D P<400 \mathrm{VU})$ and high-energy wind environment (400 VU $<D P$ ). Beside, the wind regime could be characterized depending on the wind unidirectional index as: uni-modal wind regime $\left(0.7<\frac{R D P}{D P}\right)$, bi-modal wind regime $\left(0.3<\frac{\mathbb{R D P}}{D P}<0.7\right)$ and complex wind regime $\left(0.3>\frac{\mathbb{R D P}}{\overline{D P}}\right)$.

For the period 1975-2014, seasonal drift potentials and its derived parameters were calculated in order to characterize the wind regime pattern, and the wind environment in terms of sand transporting energy.

\subsection{Climatic data and potential of dune mobility}

Dune mobility aptitude is often expressed by indexes. Based on Wasson (1984), Lancaster (1988) developed the climatic dune mobility index $M$ using the effective precipitation ${ }^{P} / P E$ and the wind energy $W$ as:

$$
M=\frac{W}{P / P E}
$$


Where $W$ express the effective wind ratio or sand transport potential, it is calculated as the annual percentage of time the wind velocity exceeding sand transport threshold (6 $\mathrm{m} / \mathrm{s}$ ), and ${ }^{P} / P E$ is the ratio between the annual average precipitation $P$ and the annual

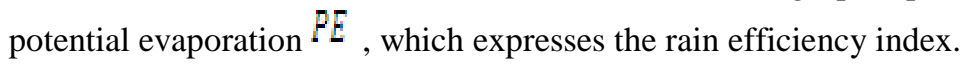

According to Lancaster (1988), dune mobility depends on critical $M$ values as: sand dune surfaces are inactive when $(50>M)$; dunes are inactive excepting for crest areas when $(50<M<100)$; dunes are active but interdunes areas stabilized by vegetation if $(100<M<200)$; and dunes are fully active when $(M>200)$. For the 40 years period, annual precipitations, evapotranspirations and effective wind ratios were summarized as yearly records to obtain aridity and dune mobility indexes, temporal variability of climate parameters has also been discussed.

\section{RESULTS AND DISCUSSION}

\subsection{Wind distribution}

Analysis of surface wind records showed that the period from March to August is the most exposed to wind activity (Table 1). This is recognizable by means of strongest monthly average wind speed ranging from $3 \mathrm{~m} / \mathrm{s}$ in August to $4 \mathrm{~m} / \mathrm{s}$ in May. Inversely, lowest calm time (null wind speed) occurs and ranges from $31 \%$ (March) to $21 \%$ (May). From March to July, the effective wind occurrence is more significant, especially in March and May (27 and $26 \%$ respectively).

Table 1. Monthly frequency percentage of the wind categories $(\mathrm{m} / \mathrm{s})$ and average wind speed at the station Sidi Mahdi (1975-2014).

\begin{tabular}{|c|c|c|c|c|c|c|c|c|}
\hline \multirow{2}{*}{ Month } & \multicolumn{7}{|c|}{ Wind speed categories } & \multirow{2}{*}{ Average wind speed (m/s) } \\
\cline { 2 - 8 } & Calm & $<2$ & $2-4$ & $4-6$ & $6-8$ & $8-10$ & $>10$ & \\
\hline Jan. & 43 & 0,7 & 22,3 & 18,6 & 8,9 & 3,3 & 2,3 & 2,6 \\
\hline Feb. & 37 & 0,8 & 23,4 & 21,0 & 9,7 & 4,1 & 3,4 & 2,9 \\
\hline Mar. & 31 & 0,9 & 20,9 & 24,5 & 12,0 & 5,8 & 4,4 & 3,5 \\
\hline Apr. & 24 & 0,6 & 20,7 & 27,2 & 14,9 & 6,7 & 5,0 & 3,9 \\
\hline May & 22 & 0,6 & 22,0 & 29,1 & 15,5 & 6,1 & 4,4 & 4,0 \\
\hline June & 26 & 0,7 & 23,4 & 28,9 & 13,5 & 5,0 & 2,5 & 3,6 \\
\hline Jul. & 28 & 0,8 & 27,3 & 28,6 & 10,5 & 2,9 & 1,5 & 3,2 \\
\hline Aug. & 30 & 0,8 & 28,2 & 27,7 & 8,9 & 2,8 & 1,1 & 3,0 \\
\hline Sep. & 33 & 0,7 & 26,5 & 25,7 & 9,7 & 2,6 & 1,5 & 2,9 \\
\hline Oct. & 38 & 0,8 & 25,6 & 22,7 & 7,9 & 2,5 & 1,7 & 2,7 \\
\hline Nov. & 41 & 0,8 & 23,5 & 20,6 & 8,2 & 3,0 & 1,9 & 2,6 \\
\hline Dec. & 44 & 0,9 & 23,6 & 18,6 & 7,7 & 2,7 & 1,9 & 2,4 \\
\hline
\end{tabular}

\subsection{Potential of sand drift and wind regime}

Similar to the effective wind distribution, amounts of sand drift potential were also marked by seasonal variability (Table 2), drift potential ranges from $42 \mathrm{VU}$ (autumn) to $113 \mathrm{VU}$ (spring) in well accordance with the net drift potential, which is maximum during winter and spring seasons (32 VU). During summer season, resultant drift direction is about 62 degrees; this means that sand movement direction is toward the west-southwest. During 
the other seasons, the $R D D$ ranges from 302 to 314 degrees which implies that sand transport direction is mostly toward the southeast.

\section{$R D P$}

The unidirectional index $\overline{D P}$ ranges from 0.24 (autumn) to 0.56 (winter); this reflects important directional variability and confirms that prevailing wind blow from different directions. For the whole period 1975-2014, the mean drift potential was about 258 VU, and the resultant drift potential $R D P$ was estimated to be $86 \mathrm{VU}\left(6 \mathrm{~m}^{3}\right.$ of creping sand across $1 \mathrm{~m}$ land width per year), this value is comparable with $282 \mathrm{VU}$ obtained by Breed et al (1979) for 10 years period. Both less than $400 \mathrm{VU}$, these values allowed classifying the region of Touggourt among the intermediate-energy wind environment (Fryberger \& Dean, 1979).

Table 2. Directional distribution of the seasonal drift potential, and summary of resultant drift potential, resultant drift direction and directional variability index for the station Sidi Mahdi (1975 - 2014).

\begin{tabular}{|c|c|c|c|c|c|c|}
\hline & Autumn & Winter & Spring & Summer & Annual* & Annual** \\
\hline $\mathrm{N}$ & 4,5 & 9,5 & 18,4 & 4,5 & 36,9 & - \\
\hline NNE & 2,2 & 1,5 & 6,5 & 2,7 & 13 & - \\
\hline $\mathrm{NE}$ & 2,4 & 1,5 & 4 & 3,3 & 11,3 & - \\
\hline ENE & 1,7 & 1,7 & 4,1 & 5,3 & 12,7 & - \\
\hline $\mathrm{E}$ & 2,2 & 1,2 & 8,5 & 8,2 & 20,1 & - \\
\hline ESE & 1 & 0,2 & 2,5 & 2,2 & 5,9 & - \\
\hline SE & 1 & 0,1 & 1,9 & 1,2 & 4,3 & - \\
\hline SSE & 0,7 & 0,3 & 2,1 & 1,6 & 4,8 & - \\
\hline $\mathrm{S}$ & 2,1 & 1,3 & 4,6 & 2,9 & 10,9 & - \\
\hline SSW & 3 & 2,3 & 4,8 & 2,4 & 12,5 & - \\
\hline SW & 5,2 & 1,5 & 9,3 & 2,2 & 18,2 & - \\
\hline WSW & 1,8 & 4,7 & 11 & 1,3 & 18,8 & - \\
\hline $\mathrm{W}$ & 3 & 9 & 11,3 & 2,5 & 25,8 & - \\
\hline WNW & 3,4 & 6 & 6,7 & 0,9 & 17,1 & - \\
\hline NW & 3,4 & 6,7 & 6,6 & 2,2 & 18,9 & - \\
\hline NNW & 3,9 & 8,6 & 11,2 & 2,8 & 26,5 & - \\
\hline Total DP (VU) & 42 & 56 & 113 & 46 & 258 & 282 \\
\hline RDP (VU) & 10 & 32 & 32 & 12 & 86 & 113 \\
\hline$\frac{R D P}{D P}$ & 0,24 & 0,56 & 0,28 & 0,26 & 0,33 & 0,4 \\
\hline RDD (degree) & 302 & 311 & 314 & 62 & 320 & - \\
\hline Direction & WNW & NW & NW & ENE & NW & NW \\
\hline
\end{tabular}

Annual sand rose (Fig. 2) shows that effective winds blow from different directions, especially north, west and east; this interaction can be confirmed by the low directional variability index estimated to be 0.33 , resultant drift direction $R D D$ (320 degrees) indicated that sand transport direction is toward the southeast.

Wind regime can be recognized as complex due to the interaction of three dominant components of the northern Sahara wind regimes; autumn northerlies, winter westerlies (resulting from Atlantic perturbations), summer northeasterlies and the southwesterlies 
prevailing winds which result from cyclonic circulation and frontal passages (Perret, 1935; Capot-Rey, 1946; Breed et al, 1979; Shao, 2008).

The inter-annual distribution of sand drift amounts was characterized by important variability during the considered period (Fig. 3), drift potentials ranged from lowest value in 2012 (104 VU) to highest value in 1975 (693 VU). Intermediate wind energy is mostly recognized for 25 years, low energy for 9 years, while the years 1975, 1976, 1979, 1985, 1988 and 1993 were exceptionally marked by high wind energy.

It is obvious that the windiness $W$ (effective wind percentage) is the main factor determining the sand transport capacity, years of significant $D P$ are often marked by important effective wind occurrence, and this could be confirmed by the coefficient of linear regression which is about 0.6 (Fig. 4).

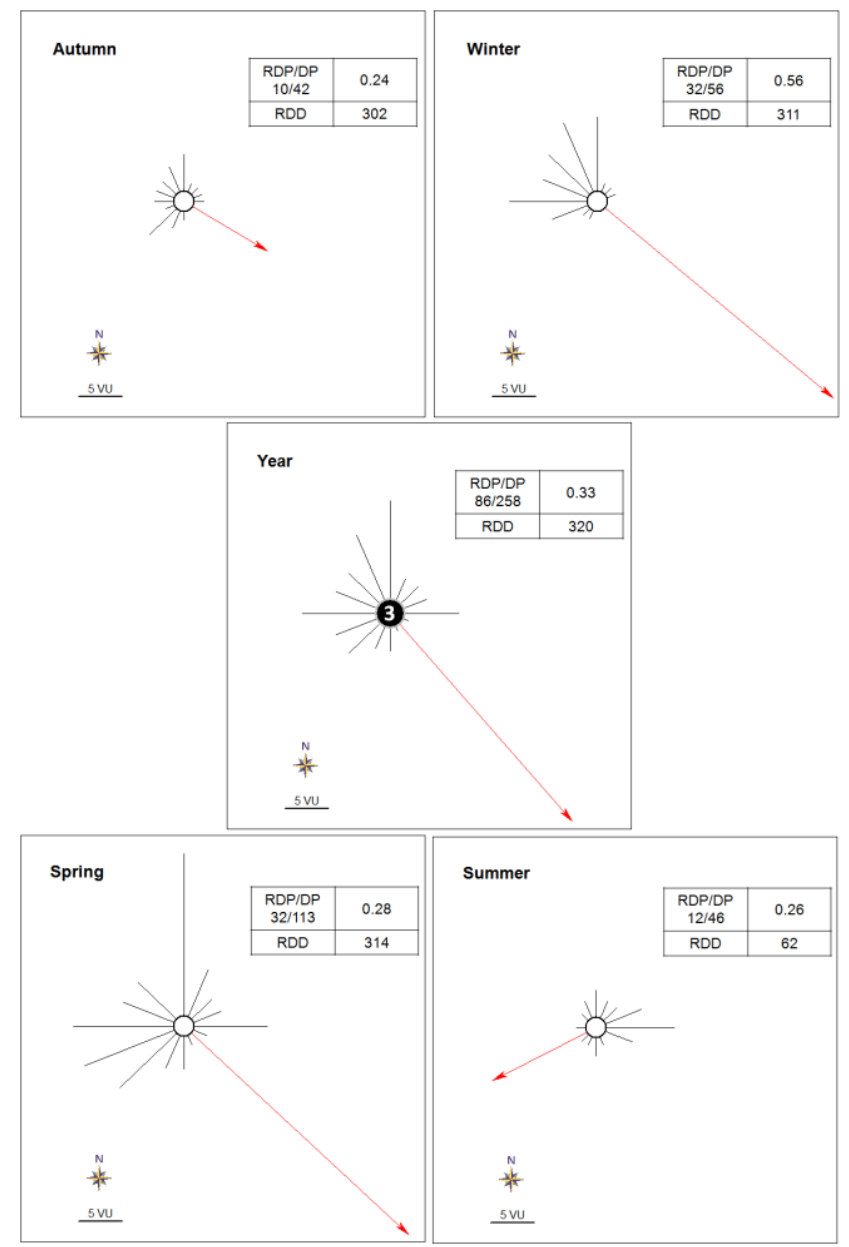

Fig. 2 Seasonal and annual sand roses in the region of Touggourt during the period 1975-2014, each arm represents the drift potential in VU (referring to the scale) from each of the 16 directions toward the center circle; red arrow indicates the sand movement trend, the number inside the center circle in the annual sand rose is a reduction factor, by which the directional DP was divided to simplify the plotting. 


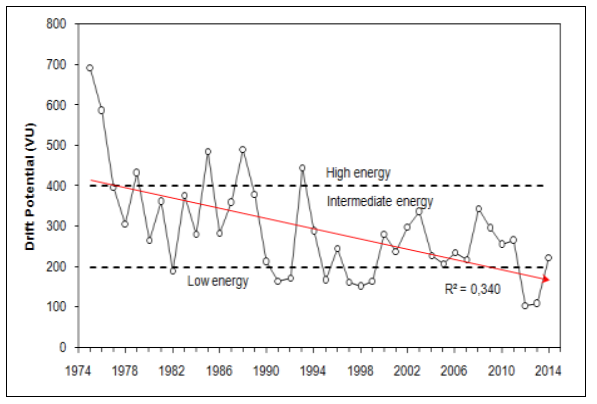

Fig. 3 Inter-annual variations of $D P$ in the region of Touggourt $(1975-2014)$, the red line refers to the regression trend line, the dashed lines refer to the high and low energy threshold.

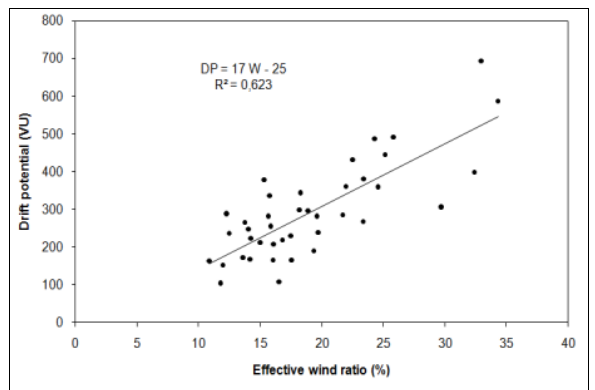

Fig. 4 Linear regression expressing the relationship between annual drift potentials (VU) and annual percentage of effective winds $\mathrm{W}$ (\%) for the station Sidi Mahdi (1975 - 2014).

\subsection{Sand dune mobility}

In this part of the northern Sahara, precipitations are particularly scarce, the mean annual rainfall is about $69 \mathrm{~mm}$ (1975-2014), and they ranged from $12 \mathrm{~mm}$ (1989) to 156 $\mathrm{mm}$ (2009). Differently, evapotranspiration values were particularly high because of the high-temperature and long-term of insulation; it oscillated between $1619 \mathrm{~mm}$ (2009) and $4109 \mathrm{~mm}$ (1985). Consequently, effective precipitation was insignificant $\left({ }^{P} / P E \approx 0.1\right)$.

Dune mobility index rate (713) was well superior to 200 (Fig. 5), this refers to low values of the effective precipitations $(P / P E)$, and indicates that sand dunes are fully active (Lancaster, 1988), excepting in 2009 where the lowest $M$ value (190) is mainly related to the highest precipitation and the lowest evapotranspiration ever recorded during the period (156 $\mathrm{mm}$ and $1619 \mathrm{~mm}$ respectively), this value is lower than 200 and indicates that the dunes could be active except for interdunes. It has been observed that the effective precipitation was a determinant factor in dune mobility: Years of high $M$ values were singularized by lowest values of the aridity index, and this can be confirmed on distinct relationship between the two parameters, the coefficient of power regression was about 0.8 (Fig. 6), confirming that $M$ values are inversely proportional to ${ }^{P} / P E$ rates.

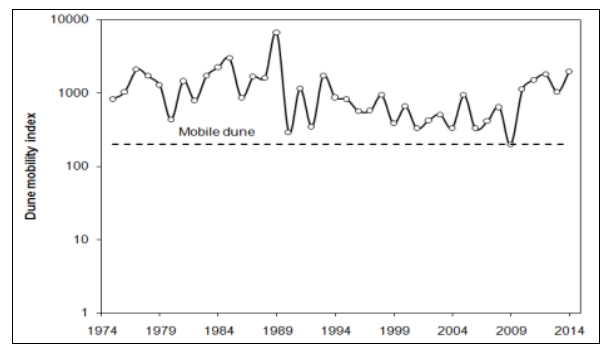

Fig. 5 Inter-annual variations of dune mobility index (Sidi Mahdi, 1975-2014).

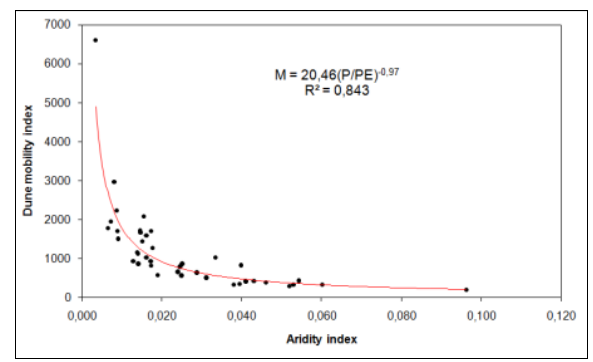

Fig. 6 Power regression between aridity and dune mobility indexes (Sidi Mahdi, 1975-2014). 


\subsection{Sand encroachment hazard}

Along the Touggourt-Djamâa railroad, several sections are covered with large sand accumulations (Fig. 7). These accumulations are mainly controlled by natural and manmade obstacles; natural barriers correspond to quaternary buttes resulting from the miopliocènes deposits erosion (gypsum sands). Since these buttes are juxtaposed with the railway, they represent stopping barriers face the eastern moving sands. Consequently, leedunes are accumulated on the track downwind of the easterlies (Trade winds). To protect the railroad, concrete railroad ties have been laid close and parallel to the track. However, this inappropriate control action caused more sand accumulation, because these impermeable obstacles contributed to trapping more moving sediments under the effect of northerlies, westerlies and easterlies effective winds.
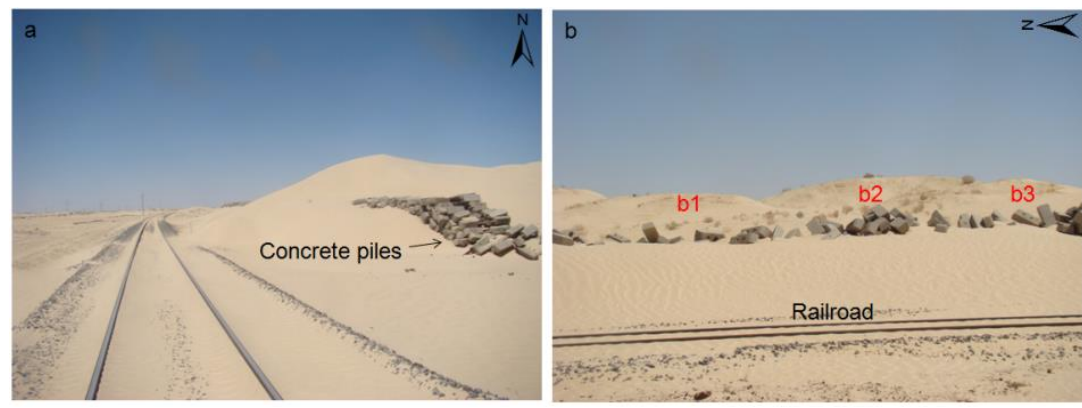

Fig. 7 (a) Effect of concrete piles on trapping moving sands; (b) Effect of concrete piles and buttes barriers (b1, b2 and b3) on sand accumulation over the railroad.

\section{CONCLUSION}

The hyper aridity of the climate is manifested by a prolonged rainfall deficit, extremely high temperatures, evapotranspiration and insignificant plant cover rate. These conditions contribute on increasing the wind erosion in the study area. The amount of drift potential for the period 1975-2014 was estimated to $258 \mathrm{VU}$; this implies that the region of Touggourt can be classified among the intermediate-energy wind environment, with a complex wind regime; this latter is related to the interaction of westerlies, northerlies, easterlies and northeasts prevailing winds, which leads to transport sand toward multiple directions, especially the southeast accordingly to the resultant drift direction (320 degrees). Sand dunes are unvegetated and are subject to high mobility; the values of the dune mobility index were largely above 200, which reflect the important capacity for dune migration. The use of inadequate control techniques had perceptibly contributed on amplifying the risk impacts. To mitigate damages, it is recommend that obstacles from both sides the railroad should be removed, topographic buttes should be re-profiled to give them an aerodynamic shape and gentle slopes; this may accelerate the air flow and prevent sand accumulation. Beside, concrete piles should be eliminated to prevent sand trapping.

\section{ACKNOWLEDGEMENTS}

This research has been supported by the Center of Scientific and Technical Research on Arid Regions (CRSTRA, Algeria). 


\section{R E F E R E N C E S}

Al-Awadhi, J., Al-Helal, A. \& Al-Enezi, A. (2005) Sand drift potential in the desert of Kuwait. Journal of Arid Environments, 63, 425-438.

Bagnold, R.A. (1941) The physics of blown sand and desert dunes. Methuen \& Co. Ltd. London.

Belly, P.Y. (1964) Sand movement by wind. US Army Corps of Engineers. Coastal Eng. Research Center Tech.

Bensaid, A. (2006) SIG et télédétection pour l'étude de l'ensablement dans une zone aride : le cas de la wilaya de Nâama (Algérie). Université Es-Senia-Oran, UJF et laboratoire espace géographique et aménagement du territoire.

Bisson, J. (2003) Mythes et réalités d'un désert convoité : Le Sahara. L'Harmattan. Paris.

Boulghobra, N., Hadri, T. \& Bouhana, M. (2014) Using Landsat imagery for monitoring the spatiotemporal evolution of sanding in drylands, the case of In-Salah in the Tidikelt (southern Algerian Sahara). Geographia Technica, 9 (1), 1-9.

Boulghobra, N., Merdas, S. \& Lakhdari, F. (2015) Sand encroachment in the Saharan Algeria; the not declared disaster - Case study: In-Salah region in the Tidikelt. Planet@Risk, 3, 1-5.

Breed, C.S., Fryberger, S.G., Andrews, S., McCauley, C., Lennartz, F., Gebel, D. \& Horstman, K. (1979) Regional studies of sand seas, using Landsat (ERTS) imagery. In: McKee, E.D. (eds.) A study of global sand seas, geological survey professional paper, US government printing office, Washington, pp. 305-398.

Callot, Y. (1987) Géomorphologie et paléoenvironnement de l'Atlas saharien au Grand Erg Occidental: Dynamique éolienne et paléolacs holocènes. Thèse de doctorat d'état. Paris 6.

Capot-Rey, R. (1946) Études récentes sur le climat de l'Afrique du nord et du Sahara. Annales de Géographie, 297, 39-48.

Chepil, W.S. \& Woodruff, N.P. (1963) The physics of wind erosion and its control. In: Norman, A.G. (eds.) Advances in agronomy, V15, Academic Press, New York, London, pp. 211-302.

Cornet, A. (1961) La géologie de l'Oued Righ. Terres et Eaux, 37, 18-24.

Dubief, J. (1953) Essay on surface hydrology in the Sahara. Department of Scientific Studies. Algiers.

Fryberger, S.G. \& Dean, G. (1979) Dune forms and wind regime. In: McKee, E.D. (eds.) A study of global sand seas, geological survey professional paper, US government printing office, Washington, pp. 137-170.

Greeley, R. \& Iversen, J.D. (1985) Wind as geological process. Cambridge University Press, Cambridge.

Lancaster, N. (1988) Development of linear dunes in the southwestern Kalahari, Southern Africa. Journal of arid environments, 14, 233-244.

Mainguet, M. (1991) Desertification, natural back-ground and human mismanagement. Springer Verlag.

Ozenda, P. (1991) Flora of Sahara. CNRS. Paris.

Perret, R. (1935) Le climat du Sahara. Annales de Géographie, 248, 162-186.

Shao, Y. (2008) Physics and modelling of wind erosion. Springer Science and Business Media.

Wasson, R.J. (1984) Late quaternary paleoenvironments in the desert dune fields of Australia. In: Vogel, J.C. (eds.) Late Cainozoic palaeoclimates of the southern hemisphere, Rotterdam, Balkema, pp. 419-432. 